\title{
New Distribution Record of Orchid Aerides maculosa on Mangrove Lumnitzera racemosa from 'Dungobachi Rai', Sindhudurg India
}

\section{Sheetal Pachpande ${ }^{*}$, Neenu Somaraj ${ }^{1}$, N. Vasudevan', Goldin Quadros ${ }^{2}$}

${ }^{1}$ Office of the Additional Principal Chief Conservator of Forests, Mangrove Cell, Wakefield House, 302, SS Ram Gulam Marg, Ballard Estate, Fort, Mumbai, Maharashtra - 400001

2Sálim Ali Centre for Ornithology and Natural History (SACON),Anaikatti, Coimbatore 641108, Tamil Nadu

Study Area: Sindhudurg, India Coordinates: $15^{\circ} 56^{\prime} 25.22^{\prime \prime} \mathrm{N} ; 73^{\circ} 31^{\prime} 11.66^{\prime \prime} \mathrm{E}$

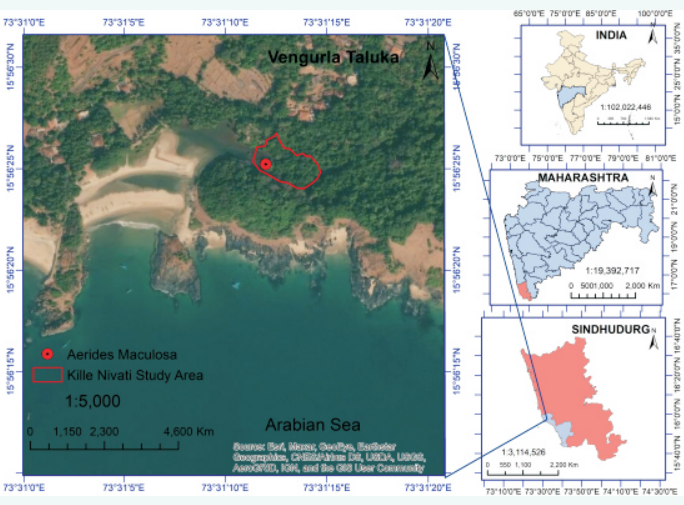

Introduction:

India has a rich history of conservation linked with the local communities. Most of the community conserved forest areas associated with religious beliefs addressed as 'Sacred groves' harbour unique flora and fauna with perennial water sources in the vicinity. Sacred groves are one of the finest instances of traditional conservation practices (Rath \& Ormsby, 2020; Gadgil \& Chandran,1992). The importance of sacred groves in conserving the local biodiversity in India was first recognized by the British Forester Dietrich Brandis as an example of 'vernacular conservation' (Brandis \& Grant, 1868). It was Gadgil \& Vartak (1975) who pioneered the documentation of sacred groves across India, as they represent surviving examples of climax vegetation that are disappearing under the influence of modernization.

Sharma \& Kumar (2020) have reported 15716 sacred groves in the country of which Maharashtra state has a total of 2837 sacred groves locally called "Devrai" that are key hot spots of biological diversity. Many major sacred groves are located in the catchment of rivers and the role of sacred groves as micro watersheds has been recognized (Godbole et al., 1996). Ecologically, sacred groves are fragments of the
Abstract

The mangrove forest comprises only 80 species of plants throughout the world, as due to harsh climatic conditions, very few plant species can survive in coastal habitats. The existence of a Sacred grove named Dungobachi Rai along the coastal region in Sindhudurg has led to the conservation of neighbouring mangrove flora, including conserving one of the rare mangrove species Heritera littoralis Dry and in the region. The area showed the presence of healthy and well-developed mangrove species. Among the five mangrove species found there, Lumnitze raracemosa Willd. showed the presence of epiphytic orchid species Aerides maculosa Lindl, which is the first distributional record from Maharashtra's mangroves. It is also evident that mangroves areas are less surveyed and therefore no reports are mentioning the presence of orchids in Mangroves from Maharashtra. Also, as orchids are very slow-growing and dependent on specific fungal associations for growth, there are chances that the species has established itself for many years and documentation of such observations is crucial in terms of conservation.

Key words: Sacred orchid, Coastal ecosysytem

original ecosystem in a region. They are refugia that often shelter plant and animal species that have disappeared elsewhere in the region, and according to Hughes (1997), they are possible centres of restoration that will aid in the conservation of unique biodiversity.

The information of coastal ecosystems like Mangroves Forest as sacred groves or community reserves is very sparse, except for the coastal states of Kerala and Goa that have records of mangrove ecosystems as sacred groves (Ray et al., 2014) while the information for Maharashtra is lacking. Mangrove forest occurs along the coastal wetlands in tropical and subtropical regions. They are characterized by halophytic (salt-loving) trees, shrubs and other plants growing in brackish to saline tidal waters. Mangrove trees dominate this wetland ecosystem due to their ability to survive in both salt and fresh water. Only plants belonging to few plant families namely Rhizophoraceae, Avicenniaceae, Sonneraciaceae, Combretaceae, Euphorbiaceae and few other families are seen to be growing in mangrove forests of Maharashtra. Very few studies from Maharashtra have mentioned the presence of the members of the family Orchidaceae in the mangrove 
dominated habitat. Willis (2017) mentioned having the ability of orchid species thriving in varied habitats except for mangrove forests where the distribution is rare.

Orchid species are known to have complex interactions with pollinators, mycorrhizal fungi and host trees and pose a threat of extinction as they are dependent on other organisms that are also being affected by habitat or climatic change (De \& Pathak, 2018). Although there are no true marine orchids, some species are epiphytic on mangrove trees in estuaries. Since orchids have specialized biological features in terms of anchorage to substrate (terrestrial and aerial), germination (usually occurs in presence of strong association with fungi) and pollination, survival in mangrove habitats may prove a challenge.

In the present report, Aerides maculosa was for the first time observed growing on one of the mangrove species that is located neighbouring Dungobachi Rai sacred grove in Sindhudurg District, Maharashtra. Dungobachi Rai is the only sacred grove in Maharashtra that is unique from all other sacred groves as it is located adjoining the mangrove forest, leading to the conservation of unique mangrove species Heritera littoralis which was first recorded from the study area during 2005 in a newspaper article published by Times of India (26th Oct., 2009). Dungobachi Devrai is believed to have existed before the era of the renowned Maratha Warrior and King Chhatrapati Shivaji Maharaj. Therefore, the trees and most probably the mangroves found at Kille Nivati might have been established before 400 years and also reflects the role of community-based conservation in preserving the important biodiversity.

Through our study, we hereby document the new distribution record of Aerides maculosa orchid species on the well-established mangrove tree of Lumnitzera racemosa which is not reported so far. The study area documented before by few researchers focusses on documentation of the rare occurrence of Heritera littoralis Dry and., however, the presence of other than mangrove species such as an epiphytic orchid in the mangrove forest is not reported. Thus, our observation is crucial in terms of understanding the changing floristic diversity in the tidally influenced mangrove habitats.

\section{Methodology:}

Study region: the Mangrove and Marine Biodiversity Conservation Foundation of Maharashtra (Mangrove Foundation) has initiated a program to regularly survey the Mangroves along the Maharashtra Coast since 2018. The documentation of the mangroves spread across the $720 \mathrm{~km}$ coastline of Maharashtra the central west coast of India is undertaken periodically since 2018 . The $720 \mathrm{~km}$ coastline comprises $17 \%$ sandy beaches, $37 \%$ rocky shores and $46 \%$ land as mudflats. Maharashtra has seven coastal districts namely Palghar in the north followed by Thane, Mumbai, Mumbai Suburbs, Raigad, Ratnagiri and Sindhudurg in the south. The global biodiversity hotspot i.e., Western Ghats covers all the districts adding to the diversity of the landscape. For this manuscript, we focus on a 0.45 -hectare area of mangrove in Vengurla taluka of Sindhudurg district, Maharashtra State, India.

The survey comprised the documentation of species found in the mangrove habitat located adjacent to Dungobachi Rai sacred grove. It was done employing opportunistic surveys as well as both the line transect and quadrat method. The seasonal study was conducted at the same sampling locations to note the diversity and phenology of the mangroves and the mangrove associate species. The mangrove and associated species were identified using standard flora viz., The Flora of the Presidency of Bombay (Cooke, 1958) and Flora of Maharashtra (Almeida, 1998). The snowball sampling method was also used to survey and interact with the local community to gather information on the mangroves, orchids and the devrai.

\section{Findings and discussion:}

Our survey was all along the Sindhudurg coast at the foothills of the Western ghats surrounded by large mango orchards from the landward side and rich mangrove vegetation towards the seaward side. This mangrove habitat is spread on 0.45 hectares land parcel adjacent to Dungobachi Rai, Sacred Grove at Kille Nivati. Most of the sacred groves from the Western ghats of Maharashtra are comparatively small in size and vary between 0.1 to 140 ha. (Godbole et al., 2008). The mangroves present here being a private land is conserved by the local Fisherfolk community with DungobaGod as the local deity. The area showed the presence of five mangrove species with one mangrove associate species (Table-1).

Table 1: The list of Mangroves and mangrove associates from the Mangrove sacred grove at Kille Nivati, Sindhudurg, Maharashtra.

\begin{tabular}{lll}
\hline Sr. No. Name of species & Family \\
\hline & True mangroves & \\
1 & Rhizophora apiculata & Rhizophoraceae \\
2 & Aegeiceras corniculatum & Primulaceae \\
3 & Lumnitzera racemosa & Combretaceae \\
4 & Excoecaria agallocha & Euphorbiaceae \\
5 & Heriteiralittoralis & Sterculiaceae \\
& Associate mangroves & \\
$\mathbf{1}$ & Cerbera odollum & Apocyanaceae \\
2 & Manilkarahexandra & apotaceae \\
\hline
\end{tabular}

Interaction with the local community representative revealed the local understanding of the conservation and importance of mangroves. Also, the collection of any material from the sacred grove is considered an offence. The community was aware that mangroves help in developing additional livelihood as traditional fishing activities such as Rampan are regularly undertaken by the community people. Despite the knowledge of the economic and 


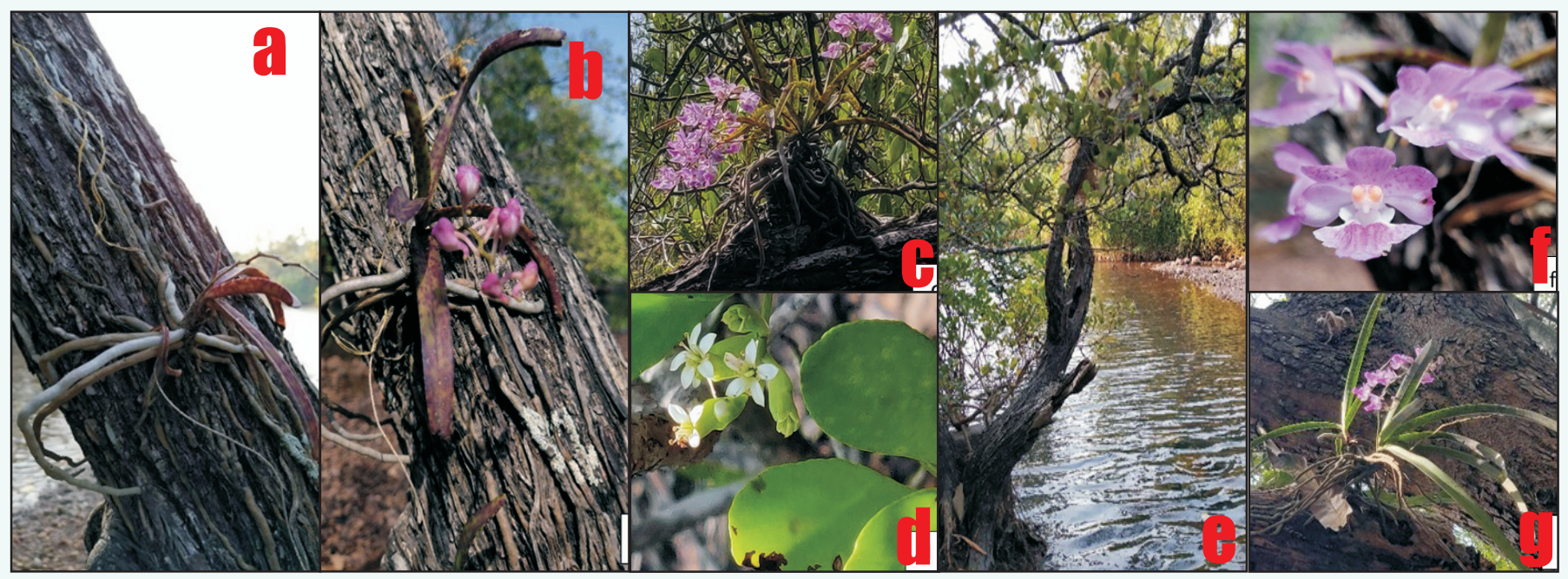

Figure-1: a) Vegetative stage of Aerides maculosa; b) Budding stage; c) flowering stage; d) Lumnitzera racemosa- tree; e) Lumnitzera racemosa flowers; f) macro view of Aerides maculosa single flower; g) Aerides maculosa on neighbouring mango orchard

medicinal uses, the mangroves adjacent to the sacred grove was unexploited, as we recorded very large and tall trees measuring over 10 meters in height around the 0.45 ha area sacred grove. Mangroves as sacred trees along the west coast of India is given very little importance. In our study, we recorded Heritiera littoralis Dry and as the dominant mangrove species followed by Rhizophora apiculata Bl., Aegeiceras corniculatum (L.) Blanco, Excoecaria agallocha L. and Lumnitzera racemosa Willd.

The presence of Heritiera littoralis Dry and from Sindhudurg, Maharashtra was first reported by Ingalhaldikar through a newspaper article (Times of India 26th October 2009) where they stated this being the only Coastal sacred grove found along the coastline of Maharashtra. The presence of Heritiera littoralis Dry and was later validated by Jugale et al. (2012) and Bhosale (2013), from two locations of Sindhudurg, one of them being around Dungobachi Rai at Kille Nivati. In our study, we observed healthy growth of mangroves which showcase the undisturbed status and natural protection provided due to the religious beliefs associated with the sacred grove. The mangroves in this habitat were able to survive well in the area despite having the stony or rocky type of shore with a very little layer of sediment exposing the intricate aboveground root system and providing strong anchorage to the ground. However, it was the presence of the Western Ghats endemic orchid species Aerides maculosa Lindl. on the mangrove species L.racemosa Willd. (Fig.-2). Also the morphological appearance of Lumnitzera racemosa Willd. exhibited a tall appearance with an average height of $15-20$ feet while other areas along the entire coastline of Maharashtra exhibited dwarf growth of maximum up to 7-9 feet only. Total 9 orchid specimens of A.maculosa were recorded growing on three tall mangrove trees of L.racemosa with the fissured stem. Probably the fissured stem helped in the growth of required fungal association on the bark of L.racemosa making it a suitable substratum for A.maculosa. The same orchid species was also recorded in neighbouring Mango (Mangifera indica) species. Both L.racemosa Willd and Mangifera indica L. belong to the family Combretaceae making it easier for the shift of Aerides maculosa to the mangrove L.racemosa Willd. in saline habitat. Orchids are known to inhabit fragile ecosystems and are extremely sensitive to their microenvironment and their reproduction largely depends on the viability of pollinators and suitable mycorrhiza (Zhang et al., 2018). Hogarth (2015), mentioned the growth of orchids on mangrove trees and also stated that most species cannot tolerate salt and the species that grow are found high only in the tall mangrove canopy, corroborating our observation. The presence of this orchid species on L.racemosa Willd indicates the suitability of the plant for establishment in a new habitat.

There is insufficient information on the orchid diversity in mangrove forests although there are no known orchid species that are exclusive to mangroves. Despite the paucity of information globally, there are few reports of orchids along with the mangrove stands. These include the orchids from the mangroves of Thailand (Santisuk, 1983) Borneo Mangroves (Choy \& Booth, 1994), Singapore Mangroves (Turner \& Yong, 1999) Venezuela mangroves (Vilarrubia, 2000) Mexico mangroves (Dejean et al., 2003), Bangladesh Sunderbans (Rahman et al., 2015), among others. Contrary to the reports from the Sunderbans in Bangladesh, the Indian Sunderbans has no specific records on the orchids from the mangroves (Gopal \& Chauhan, 2006). This corroborated with the review conducted by Kathiresan \& Rajendran (2005) on the mangrove associated flora where there is no mention of the presence of epiphytes in Indian mangroves. Roy et al. (2009) reported four species of orchids from the mangrove ecosystem of Andaman and Nicobar Islands. In recent times, Jalal \& Jayanthi, 2018 
mentioned the rare occurrence of three orchid species namely Acampe praemorsa (Rox.) Blatt., Aerides maculosa Lindl and Cottonia peduncularis (Lindl.) on the semievergreen vegetation adjoining the coastal vegetation in Maharashtra, but they have not mentioned the particular occurrence of any species surviving on mangroves in coastal habitat making this study as a new distributional record for growth of mangroves.

\section{Conclusion:}

Based on our observations and extensive comparative literature survey we found a dearth of information on the occurrence of orchids in the mangrove habitat of India. There is also a paucity of literature on the mangrove sacred groves and community reserves. Therefore, our study on the documentation of mangroves vegetation from the sacred grove and the association of orchids gains importance. The orchid A.maculosa showing preference to the true mangrove species L.racemosa Willd. is the first new distributional record from India within a vicinity of mangrove sacred grove necessitating the species and habitat conservation.

\section{References:}

Almeida, M. R. (1998): Flora of Maharashtra (Fabaceae to Apiaceae). Vol.- 2. Pub. by: Blatter Herbarium, St. Xavier's College, Mumbai, India.

Brandis, D.\& Grant, I. (1868): The Kans in the Sorab Taluka. Forest Department, Shimoga, Karnataka, India, Joint Report No. 33. Pub. by: Forest Department, Shimoga, India.

Bhosale, L. (2013): Sacred groves and conservation of adjacent species: a case study of mangroves. Proceeding of National Conference on Sacred Groves as a Repository for Ethnomedicinal Plants. Organized by Rajaram College, Kolhapur, India.

Cooke, T. (1958): The Flora of Presidency of Bombay. Pub. by: Botanical Survey of India, Vol. I -III Calcutta, India.

Dejean, A., Durou, S., Olmsted, I., Snelling, R. \& Orivel, J., (2003): Nest site selection by ants in a flooded Mexican mangrove, with special reference to the epiphytic orchid Myrmecophila christinae. J. Trop. Ecol., 19:325-341.

Roy, S.D., Krishnan, P., Grinson, G., Kaliyamoorthy, M. \& Goutham-Bharathi M.P. (2009): Mangroves of Andaman and Nicobar Islands. Project report submitted to Space Applications. Pub. by: CARI, Port Blair

De. L., \& Pathak, P. (2018): Conservation, management and utilization of orchid genetic resources. J. Orchid Soc. India, 32:81-91.

Gadgil, M. \& Vartak, V. (1975): Sacred groves of India: a plea for continued conservation. J. Bombay Nat. His. Soc., 72:314-320.

Gadgil, M. \& Chandran, M.D.S. (1992): Sacred Groves, pp. 184-187. In: Sen, G. (Ed.) Indigenous Vision: Peoples of India, Attitudes to the Environment. Pub. by: Sage Publications, New Delhi, India
Godbole, A., (1996): Role of tribals in preservation of sacred forest, pp-345-348. In: Jain SK, (ed.) Ethnobiology in Human Welfare. Pub. by: Deep Publications, New Delhi: , India.

Gopal, B. \& Chauhan, M. (2006): Biodiversity and its conservation in the Sunderban mangrove ecosystem: Aquatic Sci., 68:338354 .

Godbole, A., Punde, S., Sarnaik, J., Pashte, S. \& Gokhale, K., (2008): Revival of traditional forest conservation practices from northern Western Ghats, India. Final report of the project supported by Whitely Nature Fund UK. Pub. by: AERF, Pune, India.

Hogarth, Peter. (2015): Mangroves and Seagrasses, pp-1-. In: The Biology of Mangroves and Seagrasses. Pub. by: OUP Oxford.

Jalal, J.S. \& Jayanthi. J. (2018): An updated checklist of the Orchids of Maharashtra, India. Lankesteriana. 18(1):23-62.

Jugale, S.B., Dhumal, S.N. \& Bhosale, L.J. (2012): Occurrence of Heritiera littoralis dry and along the coast of Maharashtra State. Seshaiyana. 18(4):1-2.

Kathiresan, K. \& Rajendran, N., (2005): Coastal mangrove forests mitigated tsunami.Estuarine Coastal ShelfSci., 65:601-6o6.

Rahman, S.M., Hossain, G.M., Khan, S.A. \& Sarder, N.U. (2015): An annotated checklist of the vascular plants of Sundarban Mangrove forest of Bangladesh. Bangladesh J. Plant Taxon., 22(1):17-41.

Ray, R., Chandran, M. \& Ramachandra, T. (2014): Biodiversity and ecological assessments of Indian sacred groves. J. Forest. Res., 25(1):21-28.

Rath, S. \& Ormsby, A. (2020): Conservation through traditional knowledge: a review of research on the sacred groves of Odisha, India. Hum. Ecol., 48(4):455-463.

Choy, S.C., Booth, W.E. (1994): Prolonged inundation and ecological changes in an Avicennia mangrove: implications for conservation and management. Hydrobiologia, 285:237247.

Sharma, S. \& Kumar, R. (2020): Sacred groves of India: repositories of a rich heritage and tools for biodiversity conservation. $L$ Forest. Res., 32:899-916.

Turner, I.M. \& Yong, J.W.H.1 (1999): The coastal vegetation of Singapore, pp.- 5-23. In: Briffett C. \& Ho H. C. (Eds.) State of the Natural Environment in Singapore. Pub. by: Nature Society (Singapore).

Vilarrubia, T.V. (200o): Zonation pattern of an isolated mangrove community at Playa Medina, Venezuela. Wetland Ecol. Manag., 8(1):9-17.

Willis, K.J. (2017): State of the World's Plants: Report. Pub. by: Royal Botanic Gardens, Kew, London, UK.

Santisuk, T. (1983): Taxonomy and distribution of terrestrial trees and shrubs in the mangrove formations in Thailand. Nat. His. Bull., (SIAM Society) 31(1):63-91.

Zhang, S., Yang, Y., Li, J., Qin, J., Zhang, W., Huang, W., Hu, H. (2018): Physiological diversity of orchids. Plant Divers., 40(4):196-208, 